\title{
A longitudinal study of serum insulin-like growth factor-I levels over 6 years in a large cohort of children and adolescents with type 1 diabetes mellitus: A marker reflecting diabetic retinopathy
}

Daniel Oberg, Jenny Salemyr, Eva Ortqvist, Anders Juul and Peter Bang

The self-archived postprint version of this journal article is available at Linköping University Institutional Repository (DiVA):

http://urn.kb.se/resolve?urn=urn:nbn:se:liu:diva-149678

N.B.: When citing this work, cite the original publication.

Oberg, D., Salemyr, J., Ortqvist, E., Juul, A., Bang, P., (2018), A longitudinal study of serum insulinlike growth factor-I levels over 6 years in a large cohort of children and adolescents with type 1 diabetes mellitus: A marker reflecting diabetic retinopathy, Pediatric Diabetes, 19(5), 972-978.

https://doi.org/10.1111/pedi.12681

Original publication available at:

https://doi.org/10.1111/pedi.12681

Copyright: Wiley (12 months)

http://eu.wiley.com/WileyCDA/ 
Running Title Page

Short running title: IGF-I in children with type 1 diabetes

\section{Corresponding author:}

Professor Peter Bang, MD, PhD, MSc

Div of Pediatrics, Dept of Clinical and Experimental Medicine, Linköping University

SE-58185 Linköping, Sweden

E-mail: peter.bang@liu.se

Work: +46708226491 
A longitudinal study of serum Insulin-like growth factor I (IGF-I) levels over six years in a large cohort of children and adolescents with type 1 diabetes mellitus: a marker reflecting diabetic retinopathy

Daniel Öberg, $\mathrm{MD}^{1}$, Jenny Salemyr, $\mathrm{MD}, \mathrm{PhD}^{2}$, Eva Örtqvist, $\mathrm{MD}, \mathrm{PhD}^{2}$, Anders Juul, $\mathrm{MD}$, $\mathrm{PhD}^{3}$, Peter Bang, $\mathrm{MD}, \mathrm{PhD}, \mathrm{MSc}^{4}$

${ }^{1}$ Pediatric Department, Västervik Hospital, Västervik, Sweden

${ }^{2}$ Pediatric Endocrinology and Diabetes Unit, Karolinska Institutet and University Hospital Stockholm, Sweden

${ }^{3}$ Department of Growth and Reproduction, Rigshospitalet and University of Copenhagen, Copenhagen Denmark

${ }^{4}$ Division of Pediatrics, Department of Clinical and Experimental Medicine,

Linköping University, Linköping, Sweden

Number of words: 2287 


\begin{abstract}
OBJECTIVE

To evaluate longitudinal serum IGF-I in a large cohort of children and adolescents with type 1 diabetes in relation to $\mathrm{HbA1c}$, age, diabetes duration, and BMI, its association to height and retinopathy, and in comparison with healthy subject references.

RESEARCH DESIGN AND METHODS

A total of 2,683 serum IGF-I values were obtained from 806 children and adolescents with T1DM, from annual blood samples for up to 6 consecutive years.

RESULTS

In a multiple regression analysis IGF-I values were negatively correlated to $\mathrm{HbA1c}$ and diabetes duration, and positively correlated to BMI $(\mathrm{p}<0.001, \mathrm{p}<0.001$, and $\mathrm{p}<0.001$ respectively, adjusted $\mathrm{r}^{2}=0.102$ ). Children and adolescents with T1DM had lower mean IGF-I levels and reference interval limits compared to healthy subjects. In boys, mean (SD) IGF-I SDS levels were $-1.04( \pm 1.3)$ calculated from the healthy reference. IGF-I peaked at 15 years of age, similarly to healthy controls, but with markedly lower levels in late puberty. Girls were more affected at later stages of puberty but with a slightly less depressed overall mean IGF-I SDS of $-0.69( \pm 1.2)$. In a subgroup of 746 subjects with fundus photography, a negative correlation was seen between individual mean IGF-I SDS and preproliferative retinopathy $\left(\mathrm{p}=0.004\right.$, adjusted $\left.\mathrm{r}^{2}=0.021\right)$. In another subgroup of 84 adolescents, no correlation was seen between individual mean IGF-I SDS and target height SDS or distance to target height SDS.

CONCLUSION

Poor metabolic control and diabetes duration impact negatively on serum IGF-I levels. A low individual mean IGF-I level was associated with progression of retinopathy independently of HbA1c, age, gender and diabetes duration. Disease, sex and age related IGF-I SDS may become clinical helpful as a supplement to HbA1c in predicting the long-term outcome for children and adolescents with T1DM.
\end{abstract}




\section{Introduction}

Type 1 diabetes mellitus (T1DM) is characterized by loss of the insulin-producing $\beta$-cells in the pancreatic islets, and subcutaneous administration of insulin results in portal insulin deficiency, poor Growth Hormone (GH) receptor signalling and low circulating Insulin-Like Growth Factor-I (IGF-I) (1, 2). Modern insulin treatment regimens cannot restore normal portal insulin (3) (4) and low circulating IGF-I and GH hypersecretion (5) can only be normalized with experimental treatments which delivers insulin directly into the portal vein (6), or intra-peritoneally $(7,8)$. Another approach that normalizes circulating IGF-I and GH, lowers $\mathrm{HbA1c}$ and improves insulin sensitivity is intensified insulin treatment combined with a single daily IGF-I injection $(9,10)$.

The elevated GH secretion causes insulin resistance in children with type 1 diabetes which is particularly pronounced during puberty (11). Consequently, insulin doses have to be increased to maintain euglycemia, resulting in tissue hyperinsulinemia. The assumption that tissue hyperinsulinemia and GH hypersecretion increase tissue IGF-I production are supported by the finding of normal linear growth in children and adolescents with type 1 diabetes, despite of their markedly subnormal circulating IGF-I $(12,13)$. It is well established that increased tissue activity of IGF-I is involved in progression of nephropathy, atherosclerosis and proliferative retinopathy (14-16). Thus, low circulating IGF-I reflecting high tissue IGF-I may have direct implications on the development of long-term complications (17-20). Longitudinal serum IGF-I concentrations have been studied in smaller numbers of children and adolescents with type 1 diabetes (29). In a slightly larger study, low levels of serum IGF-I collected longitudinally from diagnosis were associated with early markers of diabetic nephropathy, supporting the concept that circulating and tissue levels of IGF-I diverge in type 1 diabetes $(21,22)$. In children and adolescents with type 1 , support for 
an association between low serum IGF-I and retinopathy is lacking while it was reported in a mixed population of adult type 1 and 2 (20) but not in adult patients with type 2 (23). The establishment of diabetes related normal reference levels for serum IGF-I provide a potential tool which may facilitate clinical management of individual patients and may become a complement to $\mathrm{HbA} 1 \mathrm{c}$ by independently predicting the long-term outcome for children with type 1 diabetes. 


\section{Research Design and Methods}

Data from all children and adolescents with type 1 diabetes attending the diabetes clinic at Astrid Lindgren Children's Hospital at Karolinska University Hospital in Stockholm since 2006. Between February 2006 and March 2013, a total of 2,683 IGF-I values were obtained from 806 patients, aged 1-18 years, with a diabetes duration of at least 6 months. Annual blood samples for up to 6 consecutive years were obtained from each individual.

\section{Assay procedure}

Immulite® 2000 IGF-I immunoassay (Siemens Healthcare Diagnostics) was used and the samples were analysed centrally by the chemistry department. The intra- and inter-assay CV based on four internal calibrators were $2.3-3.9 \%$ and $3.7-8.1 \%$, respectively.

\section{Data analysis and Statistics}

Disease-specific IGF-I reference ranges:

IGF-I values were transformed (cubic root) to obtain normal (Gaussian) distribution before calculation of mean and standard deviation which were back transformed into the corresponding mean, upper +2 Standard Deviation (SD) and lower -2 SD limits for each oneyear age range (e.g. $14-<15$ years). The IGF-I values were compared to the normal reference material of 2,555 IGF-I values from healthy children and adolescents (934 girls and 618 boys) produced by Sørensen et al $(23,24)$ using the same commercially available immunoassay. In this report we present this reference material as mean $\pm 2 \mathrm{SD}$, using the same cubic root transformation and based on values for each one-year age range.

The formula for calculating a diabetes, sex and age related z score for a given IGF-I level is $\mathrm{z}=\left(\mathrm{y}^{\wedge^{1 / 3}}-\right.$ mean $) / \mathrm{SD}$

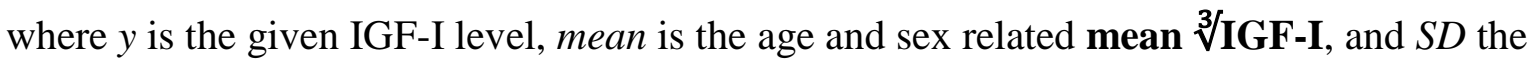
SD $\sqrt[3]{\text { IGF-I, both of the latter found in Table } 1 .}$ 
For the investigation of correlations of IGF-I Standard Deviation Score (SDS) with HbA1c, age, diabetes duration, and BMI SDS, we only used IGF-I values measured on the same day as $\mathrm{HbA1c}$, height and weight, providing a total of 1,630 simultaneous values (from the same day), 932 from boys and 698 from girls.

In a subgroup of 746 patients (423 male and 323 female, aged $14.6 \pm 3.4$ years, mean diabetes duration at the time of the last IGF-I measurement $6.7 \pm 4.0$ years, mean HbA1c 63.5 $\pm 10.8 \mathrm{mmol} / \mathrm{mol}$, and mean IGF-I SDS of $-0.81 \pm 1.1$ ) who had at least one fundus photography registered, a multiple regression analysis was performed to evaluate the correlation of preproliferative retinopathy to age, gender, diabetes duration, HbA1c and IGF-I SDS. Mean levels of IGF-I SDS and HbA1c from February 2006 to March 2013 for each patient were calculated and used, and results from fundus photography up to 18 years of age were used. Of these 746 subjects, there were 175 diagnosed with simplex rethinopathy, 2 with macular pathology, 7 with preproliferative retinopathy, and 0 with proliferative retinopathy. The mean time from the last IGF-I measurement to the fundus photography revealing preproliferative retinopathy was $56.7 \pm 60.5$ weeks.

In another subgroup consisting of 84 adolescents aged $17.4 \pm 0.8$ years, who had reached their adult height, further statistical analysis was performed comparing mean IGF-I SDS to distance to target height SDS and target height SDS. An average of 3.8 IGF-I values per individual were used for this analysis.

Data of HbA1c, weight, height, occurrence of retinopathy and parental heights was obtained from the Swedish Childhood Diabetes Registry SWEDIABKIDS.

Statistical analysis was performed with SPSS Statistics version 22 (IBM SPSS, Armonk, NY, USA).

The study was approved by the local ethical committee of Stockholm, Sweden (approval number Dnr 2010/1552-31/1). 


\section{Results}

Type 1 diabetes associated IGF-I reference values

Mean values and reference ranges (+/-2 SD) for serum IGF-I according to age in girls and boys, with and without type 1 diabetes, are shown in Fig 1A (girls) and 1B (boys). In boys with type 1 diabetes, a mean peak of just above $300 \mu \mathrm{g} / \mathrm{l}$ was observed at 15 years of age. The mean IGF-I of the healthy controls peaked at the same age with a value approximately 140 $\mu \mathrm{g} / \mathrm{l}$ higher. In girls with type 1 diabetes, a mean peak value of almost $350 \mu \mathrm{g} / \mathrm{l}$ was observed at 13 years of age. In healthy girls the mean peak was approximately $100 \mu \mathrm{g} / \mathrm{l}$ higher and occurred 1 year later.

Reference values (mean and \pm 2 SD) of serum IGF-I in girls and boys with type 1 diabetes are shown in Table 1.

IGF-I SDS relationship with HbAlc, gender, age, diabetes duration, and BMI The mean IGF-I in children and adolescents with type 1 diabetes was $-0.88 \pm 1.3$ SDS, $\mathrm{p}<$ $0.01(-0.69 \pm 1.2$ SDS in girls and $-1.04 \pm 1.3$ SDS in boys). The mean \pm SD HbA1c was 63.5 $\pm 12.9 \mathrm{mmol} / \mathrm{mol}(8.0 \pm 3.3 \%): 64.1 \pm 12.6 \mathrm{mmol} / \mathrm{mol}(8.0 \pm 3.3 \%)$ in girls and $63.1 \pm 13.0$ $\mathrm{mmol} / \mathrm{mol}(7.9 \pm 3.3 \%)$ in boys). The mean BMI SDS was $0.44 \pm 1.1(0.56 \pm 0.94$ in girls and $0.35 \pm 1.1$ in boys). A multiple regression was performed to assess the correlation of HbA1c, gender, age, diabetes duration, and BMI SDS to IGF-I SDS. A clear negative correlation between IGF-I SDS and HbA1c was found (unstandardized coefficient $b=-0.015$, $\mathrm{p}<0.001)$, meaning that a difference between 50 and $100 \mathrm{mmol} / \mathrm{mol}(6.7-11.3 \%)$ in $\mathrm{HbA} 1 \mathrm{c}$ corresponds to a difference of 0.75 SDS in IGF-I. In patients with an $\mathrm{HbA} 1 \mathrm{c} \leq 42 \mathrm{mmol} / \mathrm{mol}$ (6.0\%), IGF-I SDS was $-0.42 \pm 1.6$.

A negative correlation was also seen between IGF-I SDS and diabetes duration $(b=-0.052$, $\mathrm{p}<0.001)($ Fig 2). 
Girls had somewhat higher IGF-I SDS $(b=-0.33, p<0.001)$ than boys, as can be seen in Fig 2, and concluded from Fig 1.BMI SDS $(b=0.22, p<0.001)$ was positively correlated to IGF-I SDS.

Age $(b=0.014, p=0.137)$ was not significantly correlated to IGF-I SDS (Fig 2).

A linear multiple regression analysis was also performed to assess the correlation of HbA1c, diabetes duration, and BMI SDS to the diabetes associated IGF-I reference values established in this study. In consistency with the previous multiple regression analysis, HbA1c (coefficient $b=-0.010, p<0.001)$ and diabetes duration $(b=-0.030, p<0.001)$ were negatively correlated, and BMI SDS $(b=0.19, \mathrm{p}<0.001)$ positively correlated to the diabetes specific IGF-I SDS.

\section{IGF-I SDS and growth}

In the subgroup of 84 adolescents who had reached their adult height, this adult height was not significantly different from their mid-parental height $(\mathrm{p}=0.768)$ and the distance to midparental height was -0.021 SDS. IGF-I SDS was not correlated to distance to target height in SDS (unstandardized coefficient $b=0.020, p=0.822$, adjusted $r^{2}=-0.012$ ), or target height in SDS (unstandardized coefficient $b=-0.077, p=0.478$, adjusted $r^{2}=-0.006$ ).

\section{IGF-I SDS and relation to retinopathy}

Of the 746 patients who had a fundus photography, 7 patients had preproliferative retinopathy ( 2 male and 5 female, mean age $16.5 \pm 1.2$ years, mean diabetes duration $11.0 \pm 4.2$ years, mean $\mathrm{HbA} 1 \mathrm{c} 74.4 \pm 9.6 \mathrm{mmol} / \mathrm{mol}$ and mean IGF-I SDS $-2.27 \pm 2.0$, no concurrent autoimmune or other diagnosis).

Preproliferative retinopathy was significantly associated with a lower IGF-I SDS ( $\mathrm{p}=0.004$, adjusted $\left.r^{2}=0.021\right)$ although the effect was small, while there was no association with HbA1c, 
Table 2 and Figure 3. The presence of lower grades of retinopathy was not associated with IGF-I SDS.

\section{Conclusion}

This study demonstrates that IGF-I deficiency in children and adolescents with type 1 diabetes, using a widely used commercially available IGF-I assay, is of the magnitude of approximately 1 SDS relative to their non-diabetic peers.

Poor metabolic control is a negative predictor of IGF-I SDS in accordance with previous studies $(13,25-28)$. The children and adolescents with an HbA1c within the normal reference had a subnormal IGF-I at about -0.5 SDS, in contrast to the subjects with the highest HbA1c in which IGF-I was markedly decreased to approximately -1.5 SDS.

The IGF-I SDS were markedly lower during ages of late puberty, in agreement with earlier studies. Clayton et al (29) found a relative IGF-I deficiency mainly from pubertal stage 4 in girls and stage 3 in boys. Zachrisson et al (12) found a steep and pronounced decline in IGF-I SDS from pubertal stage 3 in girls, and a downward trend as puberty progressed in boys with diabetes. The assay used in this study has been shown to overestimate IGF-I levels compared to other assays(30), which may suggest that the current study underestimate the severity of IGF-I deficiency in type 1 diabetes. Apart from assay differences, the lack of Tanner stage related IGF-I SDS, as well as a lower mean HbA1c, in our present study may explain this less pronounced IGF-I deficiency.

Ahmed et al (26) reported reduced IGF-I SDS in both sexes during peak height velocity, with markedly low IGF-I SDS in late and post pubertal boys, in accordance with our findings. 
Interestingly, the peak in mean IGF-I in boys with type 1 diabetes occurred at the same age as in healthy boys suggesting that the age at onset and the progression of puberty was average while girls demonstrated a one year earlier peak in mean IGF-I suggesting that girls with diabetes has an earlier onset and/or faster progression of puberty.

Even in patients diagnosed during the first years of life, complications to type 1 diabetes are rarely seen before puberty, which may reflect the more pronounced IGF-I deficiency seen from the onset of puberty. Our subjects with diabetes and preproliferative retinopathy had a markedly lower mean IGF-I SDS than the average observed in patients without. This finding supports the hypothesis that in type 1 diabetes, a low circulating IGF-I reflects increased local tissue level of IGF-I, possibly via GH hypersecretion and tissue hyperinsulinemia. In mice, intraocular but not systemic IGF-I has been shown to trigger the breakdown of blood-retinal barrier (31). Furthermore, the role of IGF-I in the progression of later stages of proliferative retinopathy of the premature is well established (32). The pathophysiology of circulating and local IGF-I, and development of retinopathy as well as other long-term complications in type 1 diabetes is yet to be fully understood. Our observed correlation is limited by the low number of subjects with preproliferative retinopathy, which is expected in children and adolescents with relatively well controlled type 1 diabetes in an international perspective and relatively short diabetes duration. Further studies of childhood longitudinal IGF-I with adult follow-up is of interest to increase the number of cases of retinopathy. In such an extended study it would also be possible to study the correlation of IGF-I levels to markers of diabetic nephropathy. Our current study was limited by a low reporting of the status of urinary albumin excretion.

The close to normal IGF-I SDS observed in subjects with type 1 diabetes and the highest BMI SDS is remarkable. Since a high BMI is often associated with poorer HbA1c (33), 
insulin resistance, high insulin doses and presumably tissue hyperinsulinemia in adolescent girls it is possible that extrahepatic tissues contribute to circulating levels. This may in turn impact on pubertal onset/progress. In a study by Rogers et al(27), BMI was positively correlated to IGF-I in prepubertal but not in pubertal subjects with type 1 diabetes mellitus. In studies of children without diabetes no obvious difference in IGF-I levels has been shown between obese and non-obese children and adolescents (34-37).

Evaluation of circulating IGF-I levels in girls and boys with type 1 diabetes may become of interest as a compliment to $\mathrm{HbA} 1 \mathrm{c}$ in predicting individual risk of long term diabetic complications. Given that IGF-I levels are lowered by approximately 1 SDS depending on gender, age, BMI and metabolic control, the reported disease related reference values should be helpful in the management of individual patients. 


\section{Acknowledgements}

The authors would like to thank the children and adolescents who participated in the study. A part of this work has been presented at the European Society for Paediatric Endrocrinology annual meeting in Paris, September 2016.

\section{Duality of Interest}

P.B. has received lecture fees, consultant fees and grants from NovoNordisk, Sanofi and Lilly.

\section{Author contributions}

D.Ö. carried out data collection and analysis including the statistical analyses, contributed to the interpretation of the results, and drafted the manuscript. J.S. coordinated the study, commented on and edited the manuscript, supported data analysis, and contributed to the interpretation of the results. A.J. contributed with the data of the normal reference material, and contributed to the interpretation of the results. P.B. initiated and coordinated the study, commented on and edited the manuscript, supported data analysis, and contributed to the interpretation of the results. D.Ö. is the guarantor of this work and, as such, had full access to all the data in the study and takes responsibility for the integrity of the data and the accuracy of the data analysis. 


\section{References}

1. Daughaday WH, Phillips LS, Mueller MC. The effects of insulin and growth hormone on the release of somatomedin by the isolated rat liver. Endocrinology. 1976;98(5):1214-9.

2. Leung KC, Doyle N, Ballesteros M, Waters MJ, Ho KK. Insulin regulation of human hepatic growth hormone receptors: divergent effects on biosynthesis and surface translocation. J Clin Endocrinol Metab. 2000;85(12):4712-20.

3. Ekström K, Salemyr J, Zachrisson I, Carlsson-Skwirut C, Ortqvist E, Bang P. Normalization of the IGF-IGFBP axis by sustained nightly insulinization in type 1 diabetes. Diabetes Care. 2007;30(6):1357-63.

4. Bereket A, Lang CH, Blethen SL, Gelato MC, Fan J, Frost RA, et al. Effect of insulin on the insulin-like growth factor system in children with new-onset insulin-dependent diabetes mellitus. J Clin Endocrinol Metab. 1995;80(4):1312-7.

5. Saukkonen T, Amin R, Williams RM, Fox C, Yuen KC, White MA, et al. Dosedependent effects of recombinant human insulin-like growth factor (IGF)-I/IGF binding protein-3 complex on overnight growth hormone secretion and insulin sensitivity in type 1 diabetes. J Clin Endocrinol Metab. 2004;89(9):4634-41.

6. Shishko PI, Dreval AV, Abugova IA, Zajarny IU, Goncharov VC. Insulin-like growth factors and binding proteins in patients with recent-onset type 1 (insulin-dependent) diabetes mellitus: influence of diabetes control and intraportal insulin infusion. Diabetes Res Clin Pract. 1994;25(1):1-12.

7. Hanaire-Broutin H, Sallerin-Caute B, Poncet MF, Tauber M, Bastide R, Chale $\mathrm{JJ}$, et al. Effect of intraperitoneal insulin delivery on growth hormone binding protein, insulin-like growth factor (IGF)-I, and IGF-binding protein-3 in IDDM. Diabetologia. 1996;39(12):1498-504. 
Effect of i.p. insulin administration on IGF1 and IGFBP1 in type 1 diabetes. Endocr Connect. 2014;3(1):17-23.

9. Acerini CL, Harris DA, Matyka KA, Watts AP, Umpleby AM, Russell-Jones DL, et al. Effects of low-dose recombinant human insulin-like growth factor-I on insulin sensitivity, growth hormone and glucagon levels in young adults with insulin-dependent diabetes mellitus. Metabolism. 1998;47(12):1481-9.

10. Dunger DB, Cheetham TD, Crowne EC. Insulin-like growth factors (IGFs) and IGF-I treatment in the adolescent with insulin-dependent diabetes mellitus. Metabolism. 1995;44(10 Suppl 4):119-23.

11. Dunger DB, Acerini CL. IGF-I and diabetes in adolescence. Diabetes Metab. 1998;24(2):101-7.

12. Zachrisson I, Brismar K, Hall K, Wallensteen M, Dahlqvist G. Determinants of growth in diabetic pubertal subjects. Diabetes Care. 1997;20(8):1261-5.

13. Bonfig W, Kapellen T, Dost A, Fritsch M, Rohrer T, Wolf J, et al. Growth in children and adolescents with type 1 diabetes. J Pediatr. 2012;160(6):900-3.e2.

14. Schrijvers BF, De Vriese AS, Flyvbjerg A. From hyperglycemia to diabetic kidney disease: the role of metabolic, hemodynamic, intracellular factors and growth factors/cytokines. Endocr Rev. 2004;25(6):971-1010.

15. Clemmons DR, Maile LA, Ling Y, Yarber J, Busby WH. Role of the integrin alphaVbeta3 in mediating increased smooth muscle cell responsiveness to IGF-I in response to hyperglycemic stress. Growth Horm IGF Res. 2007;17(4):265-70.

16. Miller EC, Capps BE, Sanghani RR, Clemmons DR, Maile LA. Regulation of igf-I signaling in retinal endothelial cells by hyperglycemia. Invest Ophthalmol Vis Sci. 2007;48(8):3878-87. 
17. Grant MB, Mames RN, Fitzgerald C, Ellis EA, Caballero S, Chegini N, et al. Insulin-like growth factor I as an angiogenic agent. In vivo and in vitro studies. Ann N Y Acad Sci. 1993;692:230-42.

18. Merimee TJ, Zapf J, Froesch ER. Insulin-like growth factors. Studies in diabetics with and without retinopathy. N Engl J Med. 1983;309(9):527-30.

19. Janssen JA, Lamberts SW. Circulating IGF-I and its protective role in the pathogenesis of diabetic angiopathy. Clin Endocrinol (Oxf). 2000;52(1):1-9.

20. Amin R, Bahu TK, Widmer B, Dalton RN, Dunger DB. Longitudinal relation between limited joint mobility, height, insulin-like growth factor 1 levels, and risk of developing microalbuminuria: the Oxford Regional Prospective Study. Arch Dis Child. 2005;90(10):1039-44.

21. Amin R, Schultz C, Ong K, Frystyk J, Dalton RN, Perry L, et al. Low IGF-I and elevated testosterone during puberty in subjects with type 1 diabetes developing microalbuminuria in comparison to normoalbuminuric control subjects: the Oxford Regional Prospective Study. Diabetes Care. 2003;26(5):1456-61.

22. Wedrychowicz A, Dziatkowiak H, Nazim J, Sztefko K. Insulin-like growth factor- 1 and its binding proteins, IGFBP-1 and IGFBP-3, in adolescents with type-1 diabetes mellitus and microalbuminuria. Horm Res. 2005;63(5):245-51.

23. Sørensen K, Aksglaede L, Petersen JH, Leffers H, Juul A. The exon 3 deleted growth hormone receptor gene is associated with small birth size and early pubertal onset in healthy boys. J Clin Endocrinol Metab. 2010;95(6):2819-26.

24.

Sørensen K, Aksglaede L, Petersen JH, Andersson AM, Juul A. Serum IGF1 and insulin levels in girls with normal and precocious puberty. Eur J Endocrinol. 2012;166(5):903-10. 
25. Holly JM, Dunger DB, Edge JA, Smith CP, Chard T, Wass JA. Insulin-like growth factor binding protein-1 levels in diabetic adolescents and their relationship to metabolic control. Diabet Med. 1990;7(7):618-23.

26.

Ahmed ML, Connors MH, Drayer NM, Jones JS, Dunger DB. Pubertal growth in IDDM is determined by HbA1c levels, sex, and bone age. Diabetes Care. 1998;21(5):8315.

27. Rogers DG, Sherman LD, Gabbay KH. Effect of puberty on insulinlike growth factor I and HbA1 in type I diabetes. Diabetes Care. 1991;14(11):1031-5.

28. Palta M, LeCaire TJ, Sadek-Badawi M, Herrera VM, Danielson KK. The trajectory of IGF-1 across age and duration of type 1 diabetes. Diabetes Metab Res Rev. 2014;30(8):777-83.

29. Clayton KL, Holly JM, Carlsson LM, Jones J, Cheetham TD, Taylor AM, et al. Loss of the normal relationships between growth hormone, growth hormone-binding protein and insulin-like growth factor-I in adolescents with insulin-dependent diabetes mellitus. Clin Endocrinol (Oxf). 1994;41(4):517-24.

30. Bidlingmaier M, Friedrich N, Emeny RT, Spranger J, Wolthers OD, Roswall J, et al. Reference intervals for insulin-like growth factor-1 (igf-i) from birth to senescence: results from a multicenter study using a new automated chemiluminescence IGF-I immunoassay conforming to recent international recommendations. J Clin Endocrinol Metab. 2014;99(5):1712-21.

31. Haurigot V, Villacampa P, Ribera A, Llombart C, Bosch A, Nacher V, et al. Increased intraocular insulin-like growth factor-I triggers blood-retinal barrier breakdown. J Biol Chem. 2009;284(34):22961-9. 
al. Longitudinal postnatal weight and insulin-like growth factor I measurements in the prediction of retinopathy of prematurity. Arch Ophthalmol. 2006;124(12):1711-8.

33.

Hanberger L, Samuelsson U, Lindblad B, Ludvigsson J, SWEDIABKIDS

SCDR. A1C in children and adolescents with diabetes in relation to certain clinical

parameters: the Swedish Childhood Diabetes Registry SWEDIABKIDS. Diabetes Care. 2008;31(5):927-9.

34. Hosick PA, McMurray RG, Hackney AC, Battaglini CL, Combs TP, Harrell JS. Differences in the GH-IGF-I axis in children of different weight and fitness status. Growth Horm IGF Res. 2012;22(2):87-91.

35. Ballerini MG, Ropelato MG, Domené HM, Pennisi P, Heinrich JJ, Jasper HG. Differential impact of simple childhood obesity on the components of the growth hormoneinsulin-like growth factor (IGF)-IGF binding proteins axis. J Pediatr Endocrinol Metab. 2004;17(5):749-57.

36. Reinehr T, Panteliadou A, de Sousa G, Andler W. Insulin-like growth factor-I, insulin-like growth factor binding protein-3 and growth in obese children before and after reduction of overweight. J Pediatr Endocrinol Metab. 2009;22(3):225-33.

37. Vandewalle S, Taes Y, Van Helvoirt M, Debode P, Herregods N, Ernst C, et al. Bone size and bone strength are increased in obese male adolescents. J Clin Endocrinol Metab. 2013;98(7):3019-28. 
Tables

Table 1 - Reference values of IGF-I in girls and boys with type 1 diabetes

\begin{tabular}{|c|c|c|c|c|c|c|c|c|c|c|}
\hline \multirow[b]{2}{*}{ Age } & \multicolumn{5}{|c|}{ Girls with type 1 diabetes } & \multicolumn{5}{|c|}{ Boys with type 1 diabetes } \\
\hline & $\begin{array}{c}\text { Mean } \\
\sqrt[3]{\text { IGF-I }}\end{array}$ & $\begin{array}{c}\text { SD } \\
\sqrt[3]{\text { IGF-I }}\end{array}$ & Mean IGF-I & $-2 \mathrm{SD}$ & $+2 \mathrm{SD}$ & $\begin{array}{c}\text { Mean } \\
\sqrt[3]{\text { IGF-I }}\end{array}$ & $\begin{array}{c}\text { SD } \\
\sqrt[3]{\text { IGF-I }}\end{array}$ & Mean IGF-I & $-2 \mathrm{SD}$ & $+2 \mathrm{SD}$ \\
\hline $2-<3$ & 4.05 & 0.32 & 66 & 38 & 106 & 3.54 & 0.31 & 44 & 23 & 76 \\
\hline $3-<4$ & 4.32 & 0.53 & 81 & 33 & 159 & 3.64 & 0.49 & 48 & 18 & 101 \\
\hline $4-<5$ & 4.43 & 0.53 & 87 & 38 & 167 & 4.07 & 0.44 & 68 & 32 & 122 \\
\hline $5-<6$ & 4.69 & 0.63 & 103 & 40 & 213 & 4.28 & 0.58 & 78 & 30 & 161 \\
\hline $6-<7$ & 5.05 & 0.69 & 129 & 49 & 268 & 4.57 & 0.53 & 95 & 43 & 178 \\
\hline $7-<8$ & 5.03 & 0.57 & 127 & 58 & 237 & 4.77 & 0.59 & 109 & 46 & 213 \\
\hline $8-<9$ & 5.28 & 0.60 & 147 & 67 & 274 & 4.92 & 0.58 & 119 & 53 & 225 \\
\hline $9-<10$ & 5.46 & 0.60 & 163 & 76 & 298 & 5.15 & 0.60 & 137 & 61 & 258 \\
\hline $10-<11$ & 5.80 & 0.71 & 195 & 84 & 376 & 5.25 & 0.62 & 145 & 64 & 275 \\
\hline $11-<12$ & 6.47 & 0.88 & 271 & 104 & 558 & 5.50 & 0.62 & 166 & 76 & 307 \\
\hline $12-<13$ & 6.91 & 0.75 & 329 & 158 & 595 & 5.90 & 0.96 & 205 & 62 & 481 \\
\hline $13-<14$ & 7.03 & 0.79 & 347 & 161 & 641 & 6.40 & 0.94 & 263 & 92 & 571 \\
\hline $14-<15$ & 6.91 & 0.68 & 330 & 170 & 569 & 6.73 & 0.81 & 305 & 134 & 584 \\
\hline $15-<16$ & 6.72 & 0.67 & 304 & 155 & 526 & 6.72 & 0.69 & 303 & 152 & 532 \\
\hline $16-<17$ & 6.50 & 0.73 & 274 & 128 & 503 & 6.70 & 0.66 & 301 & 156 & 517 \\
\hline $17-<18$ & 6.50 & 0.70 & 275 & 132 & 496 & 6.35 & 0.75 & 256 & 114 & 483 \\
\hline $18-<19$ & 6.40 & 0.71 & 262 & 121 & 482 & 6.19 & 0.71 & 237 & 107 & 443 \\
\hline
\end{tabular}


Table 2 - Multiple regression analysis demonstrating the association of preproliferative retinopathy to age. gender. diabetes duration. IGF-I SDS and HbA1c (adjusted $\mathrm{r}^{2}=0.021$ ).

\begin{tabular}{|l|l|l|l|}
\hline & Unstandardized $\beta$ & Standardized $\beta$ & P \\
\hline Age & $7.637 \mathrm{E}-5$ & 0.003 & 0.948 \\
\hline Gender & 0.014 & 0.070 & 0.063 \\
\hline Duration & 0.001 & 0.050 & 0.244 \\
\hline IGFI & -0.010 & -0.115 & 0.004 \\
\hline HbA1c & 0.000 & 0.034 & 0.418 \\
\hline
\end{tabular}




\section{Figures}

Figure 1a - Mean and \pm 2 SD of IGF-I in girls

black circles and solid lines $=$ girls with type 1 diabetes; dashed line $=$ healthy controls

Figure 1b - Mean and \pm 2 SD of IGF-I in boys

black triangles and solid lines = boys with type 1 diabetes; dashed line $=$ healthy controls

Figure 2 - HbA1c. age. diabetes duration. and BMI SDS in children with type 1 diabetes correlated with their IGF-I SDS calculated from the healthy references.

black squares $=$ both genders with $95 \% \mathrm{CI}$; black circles $=$ girls; black triangles $=$ boys

Figure 3 - IGF-I SDS and HbA1c in children with type 1 diabetes. and with preproliferative retinopathy $=$ triangles. and without preproliferative retinopathy $=$ circles. 
Fig 1a

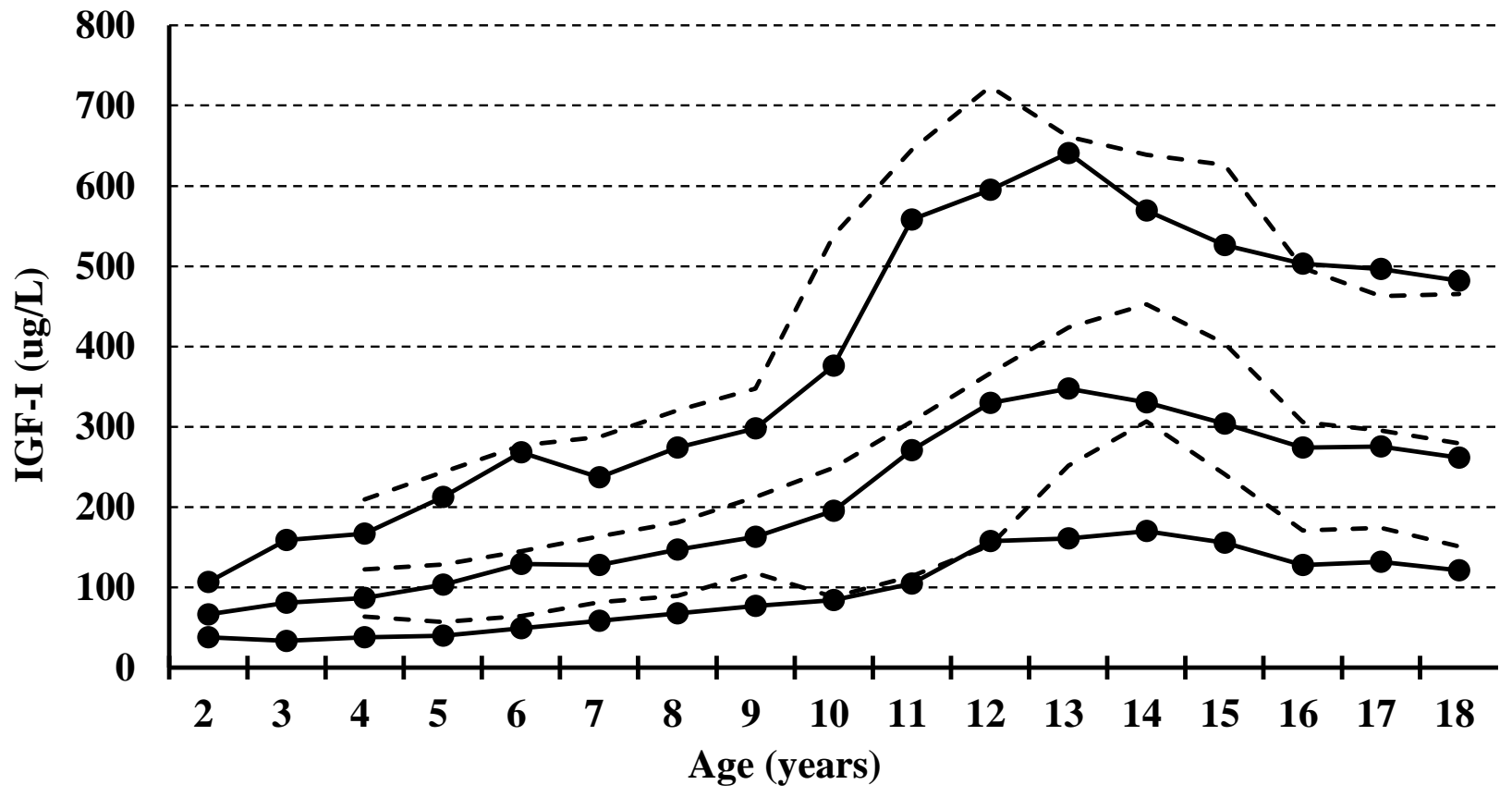


Fig $1 b$

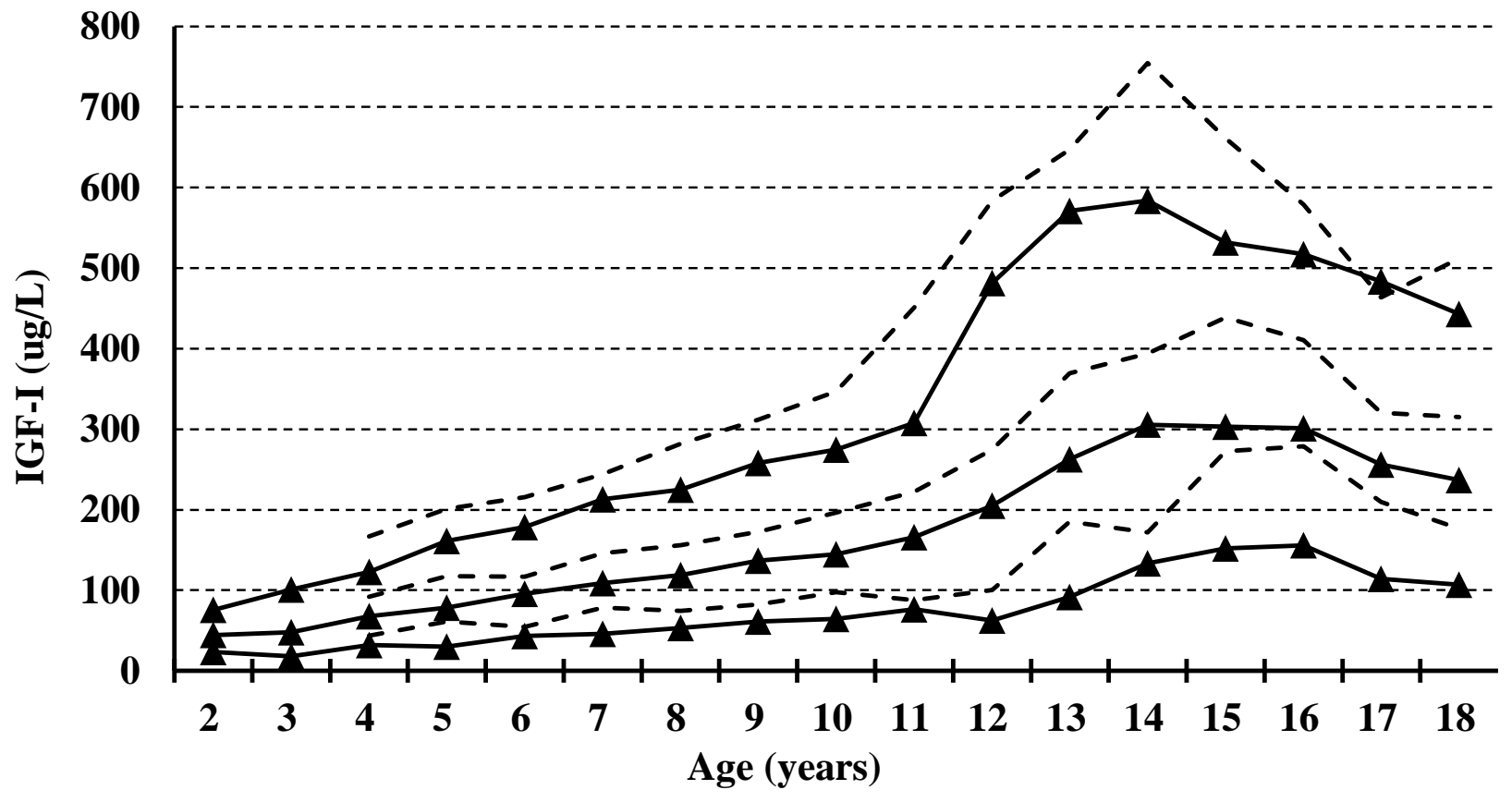


Fig 2a

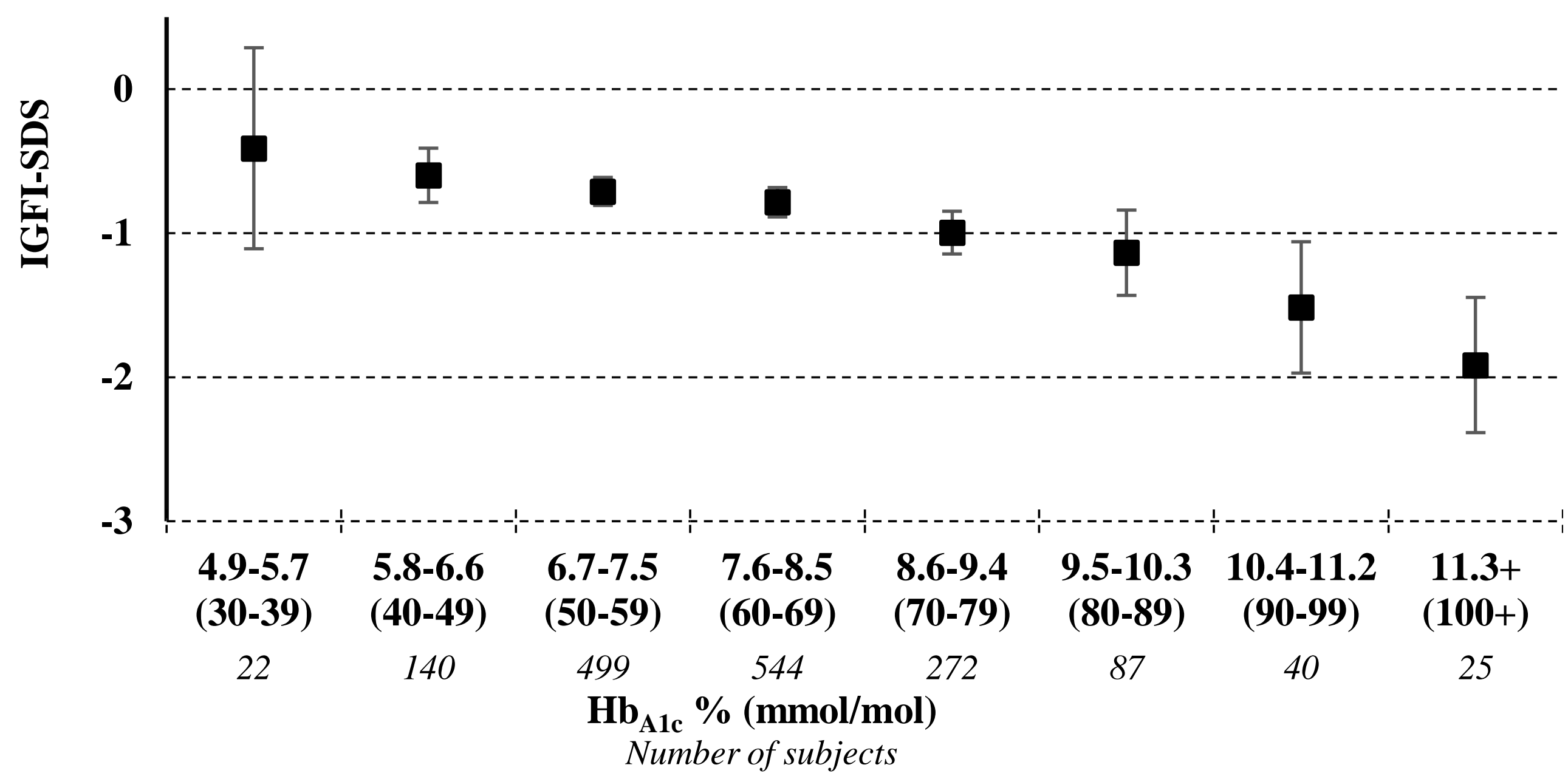


Fig 2b

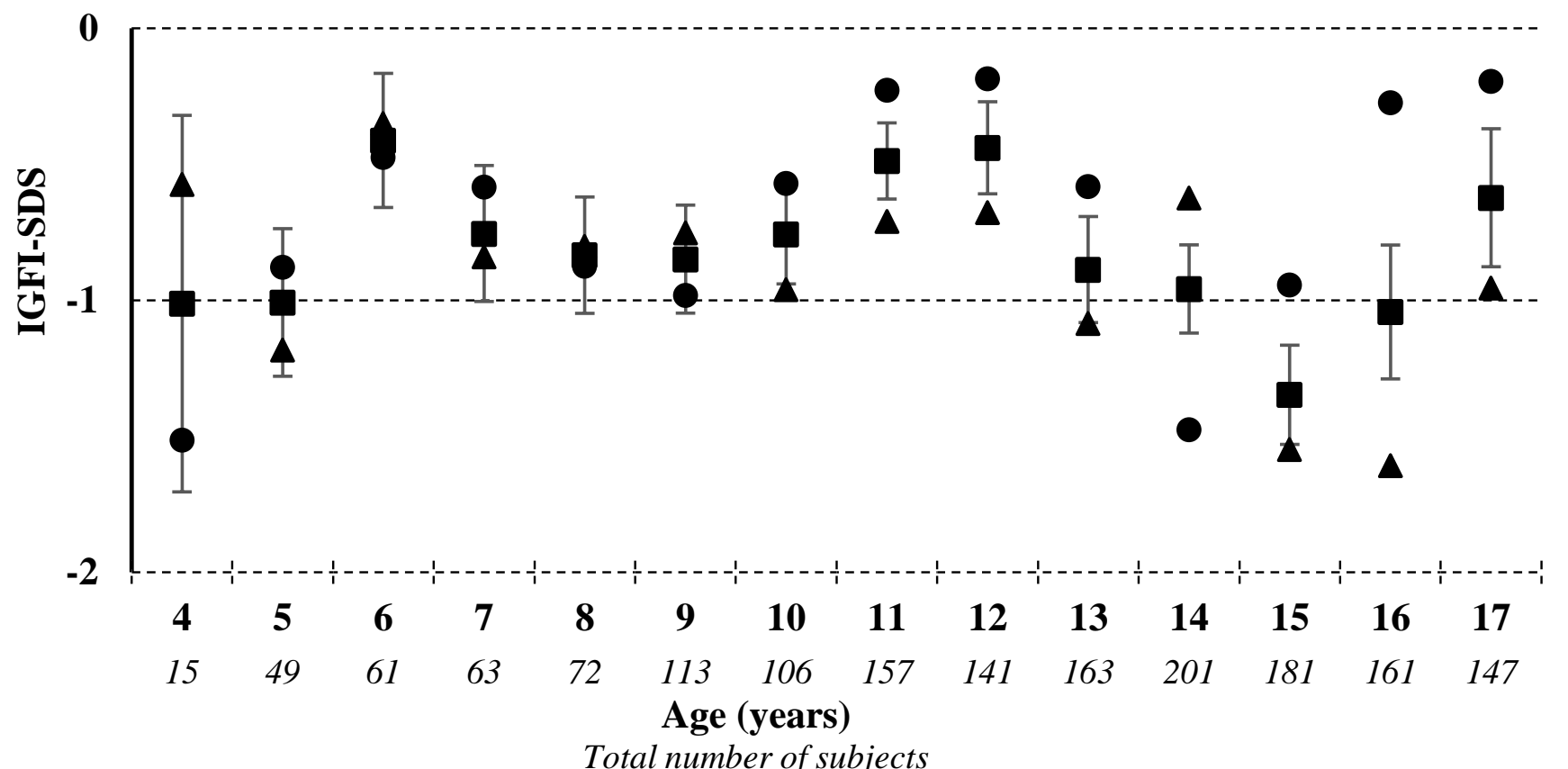


Fig 2c

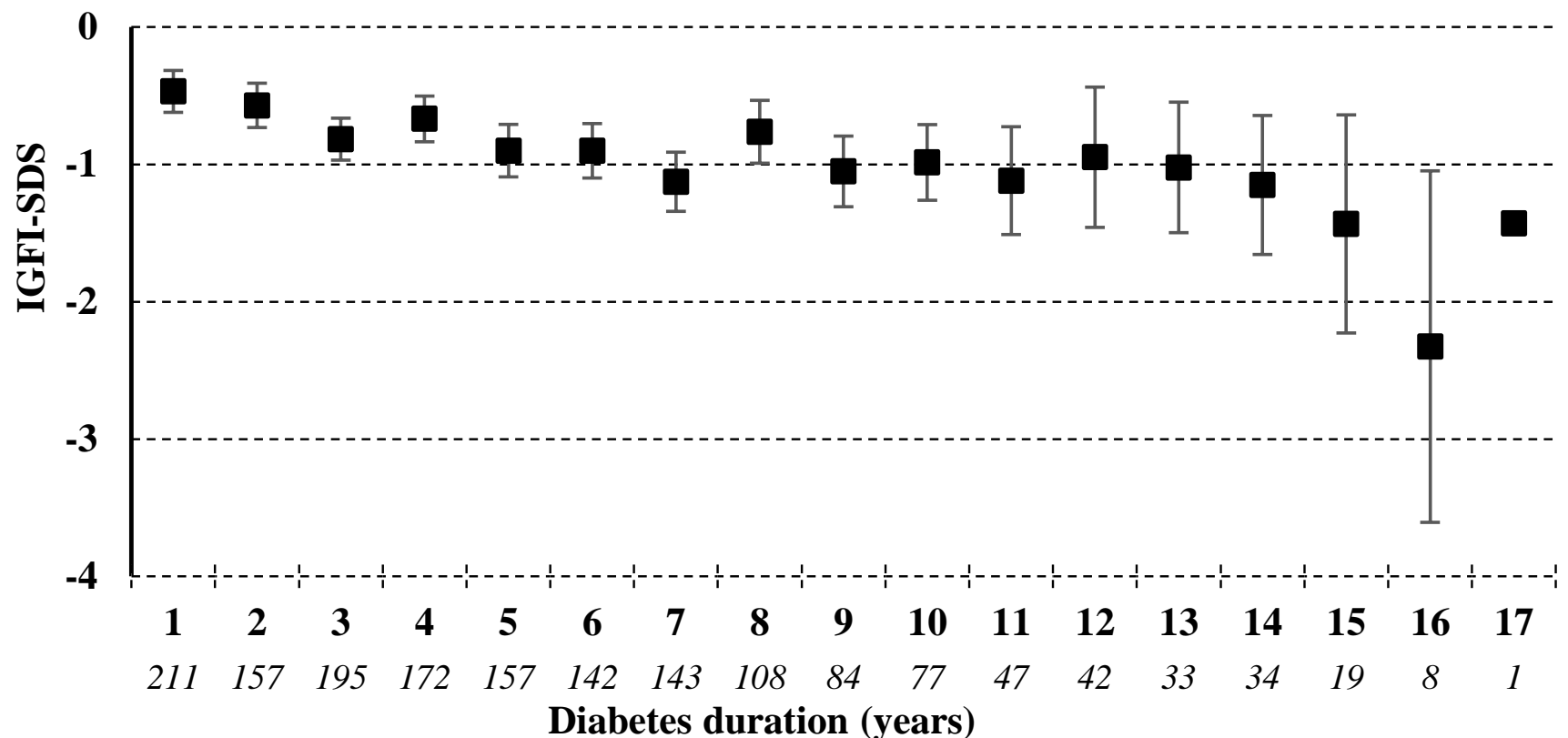

Number of subjects 
Fig 2d

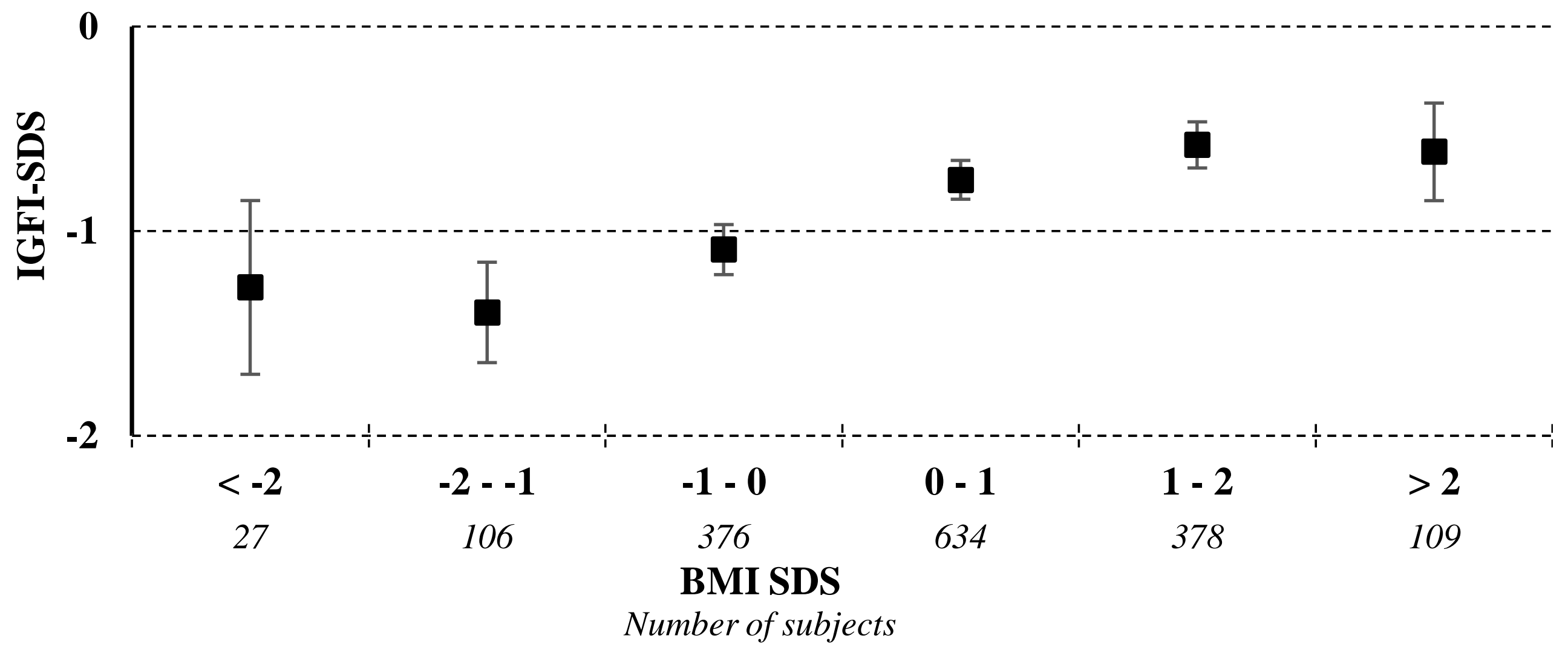


Fig 3

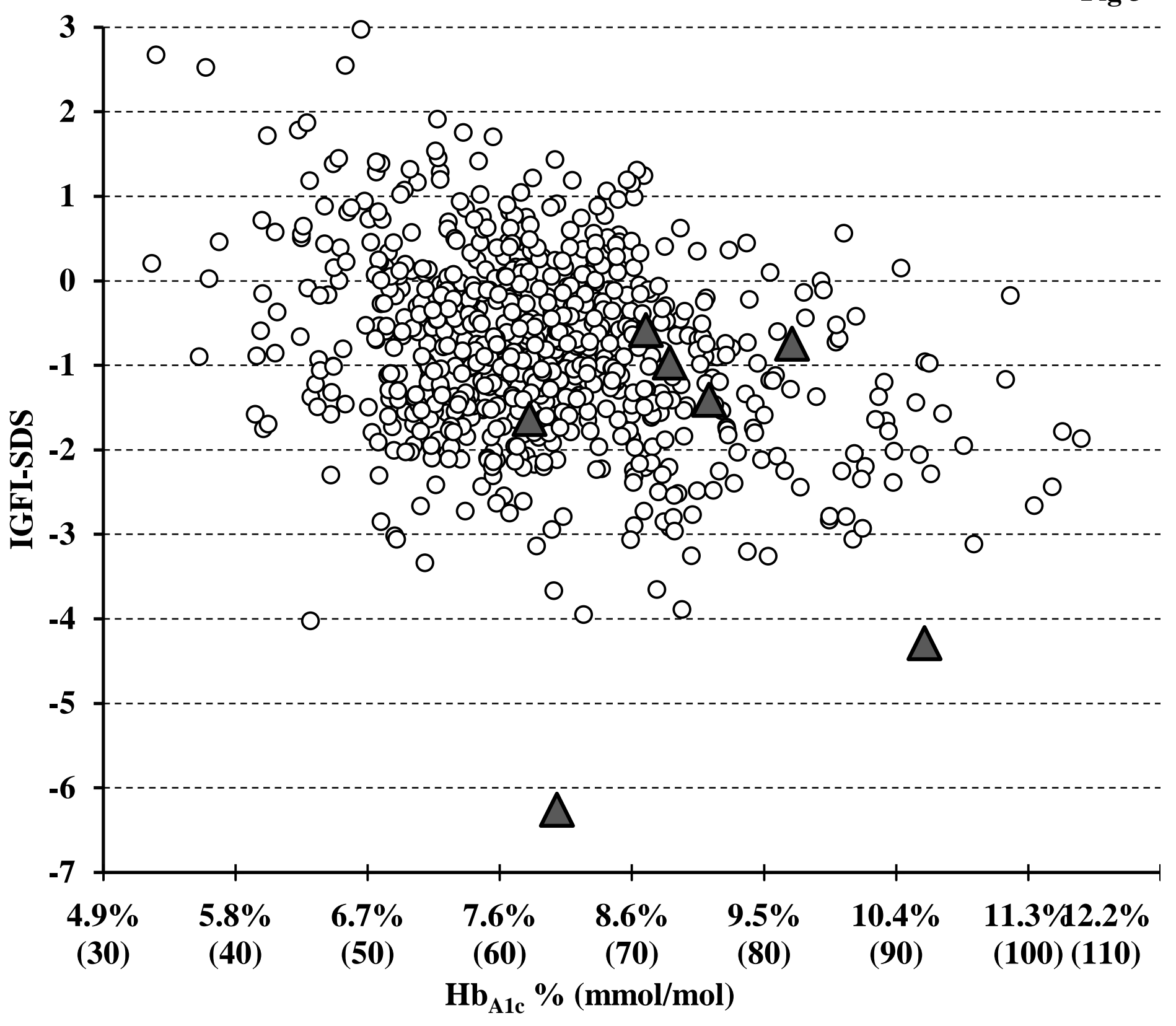

